Тихончук Л. Х. [1; ORCID ID: 0000-0002-0029-4120], д.н.держ.упр., доцент, Чубок Т. О. [1; ORCID ID: 0000-0001-6807-8232], здобувач вищої освіти другого (магістерського) рівня

${ }^{1}$ Національний університет водного господарства та природокористування, м. Рівне

\title{
ЕФЕКТИВНІСТЬ ПУБЛІЧНОГО УПРАВЛІННЯ У СФЕРІ КУЛЬТУРИ В УМОВАХ ДЕЦЕНТРАЛІЗАЦІЇ (НА ПРИКЛАДІ РІВНЕНСЬКОЇ ОБЛАСТІ)
}

У статті описано дослідження ефективності публічного управління у сфері культури у Рівненській області. Здійснено аналіз сутності та особливостей трансформації публічного управління у сфері культури в умовах реформи децентралізації. Доводиться актуальність запровадження змін у функціонуванні закладів культури 3 метою задоволення потреб місцевої громади в сучасних умовах. Акцентовано увагу на необхідності законодавчих інновацій, що забороняють нецільове використання або перепрофілювання місцевих культурних інституцій для забезпечення ефективності публічного управління. Вказується на необхідність розробки та впровадження нової моделі роботи закладів культури в умовах реформи децентралізації. Розглянуто особливості покращення функціонування установ соціальної сфери для забезпечення ефективності управління, за рахунок грантових організацій, міжнародних та українських фондів з досвіду Рівненської області.

Ключові слова: культура; децентралізація; ефективність публічного управління у сфері культури; УКФ; грант.

Постановка проблеми. У контексті впровадження реформ публічного управління на порядок денний поставлено завдання визначення концептуальних основ децентралізації культурної політики, що пов'язано 3 низкою складних фінансових та організаційних питань. Громади повинні мати можливість самостійно вирішувати проблему збереження місцевих національно-культурних та етнографічних традицій, визначати напрями розвитку закладів культури. Центральний уряд повинен бути уповноважений ефективно реалізовувати загальнодержавні програми культурного розвитку та утримання об'єктів культурної спадщини. Водночас децентралізація не повинна стати засобом політичних спекуляцій та загрожувати єдності культурного простору. 
Необхідною умовою забезпечення повноцінного розвитку сфери культури є організація та здійснення ефективного публічного управління на засадах чітко визначених принципів, що пов'язують мету зі способами ії досягнення, вказують на можливі або ж необхідні шляхи, механізми, засоби реалізації поставленої мети в розвитку культури в умовах децентралізації.

Аналіз останніх досліджень і публікацій. Питання щодо ефективності публічного управління закладами культури в умовах децентралізації розглядали у своїх працях багато вітчизняних

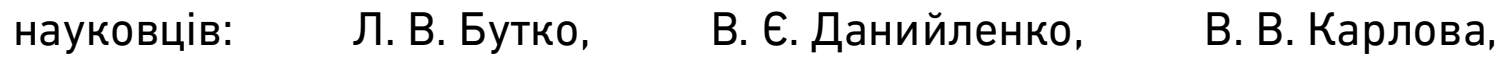
В. М. Купрійчук, А. А. Митник [1], Р. А. Небожук, Р.І. Олексенко [2], П. К. Ситник [3] та інші. Для дослідження трансформаційних процесів у Рівненській області було використано матеріали круглого столу «Децентралізаційні виклики управлінням культурою, справами молоді та спорту (Рівненський регіон)» [4].

Мета статті. Дослідити умови забезпечення ефективності публічного управління культурною діяльністю в Україні, виявити особливості фінансового та організаційного регулювання закладів культури в умовах децентралізації.

Виклад основного матеріалу. Сфера культури в Україні, що являє собою «сукупність матеріального і духовного надбання певної людської спільноти, нагромадженого, закріпленого і збагаченого протягом тривалого періоду, що передається від покоління до покоління, включає всі види мистецтва, культурну спадщину, культурні цінності, науку, освіту та відображає рівень розвитку цієї спільноти» [5], спрямовується і координується Кабінетом Міністрів України. «Головним органом у системі центральних органів виконавчої влади, що забезпечує формування та реалізує державну політику у сферах культури, державної мовної політики, популяризації України у світі, державного іномовлення, інформаційного суверенітету України та інформаційної безпеки, а також забезпечує формування та реалізацію державної політики у сферах кінематографії, відновлення та збереження національної пам'яті, міжнаціональних відносин, релігії та захисту прав національних меншин в Україні, мистецтв, охорони культурної спадщини, музейної справи, вивезення, ввезення і повернення культурних цінностей» $€$ Міністерство культури та інформаційної політики, що визначено постановою КМУ від 16 жовтня 2019 р. № 885 «Деякі питання діяльності Міністерства культури та інформаційної політики» [6]. 
Регіональний та базовий рівні управління сферою культури у Рівненській області представлені Управлінням культури та туризму Рівненської обласної державної адміністрації (далі - ОДА) та районними відділами культури, що більш детально зображено на рисунку.

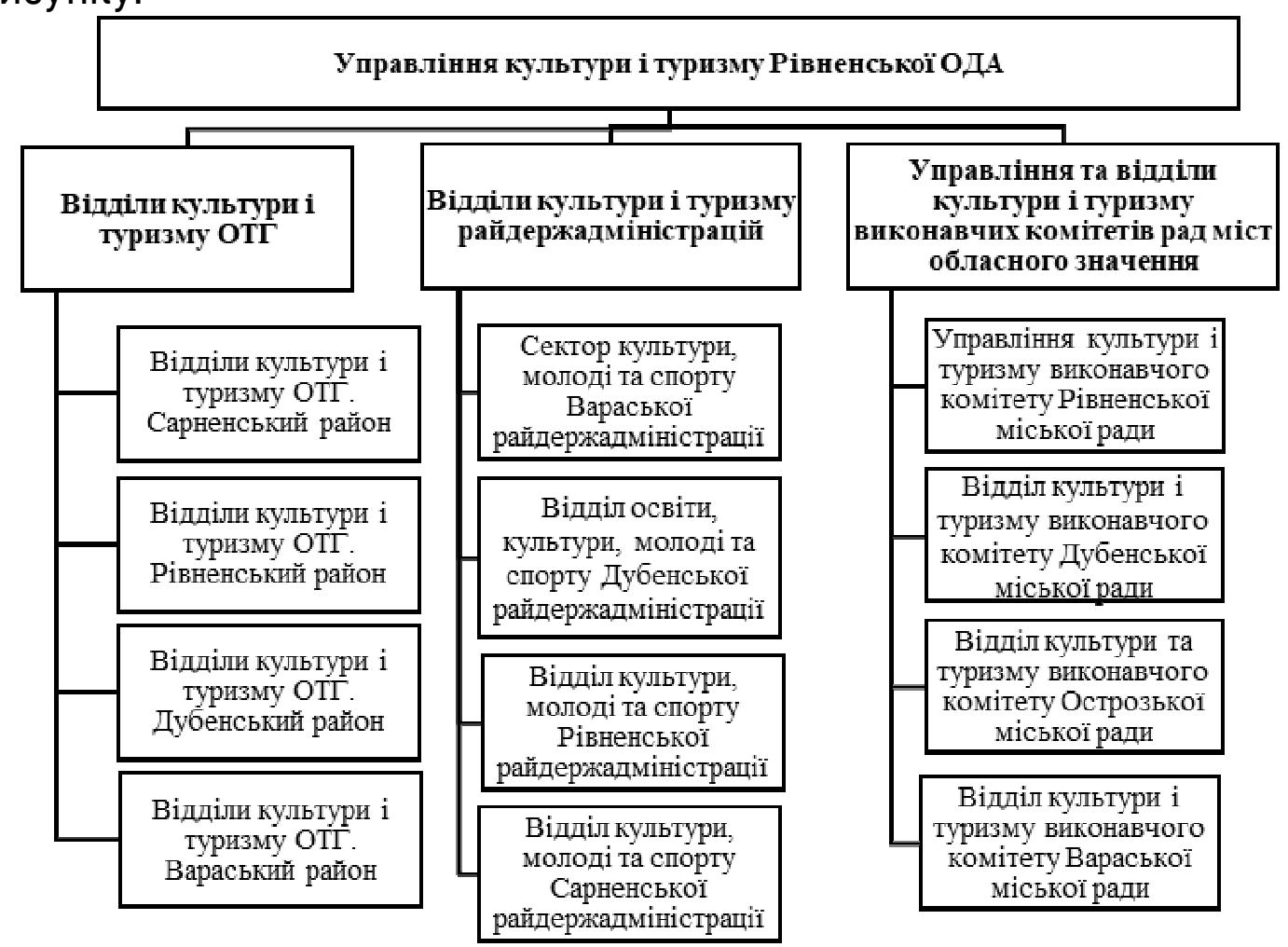

Рисунок. Система органів влади щодо реалізації державної політики у сфері культури у Рівненській області

Таким чином, система органів влади щодо реалізації державної політики у сфері культури на Рівненщині представлена управлінням культури Рівненської ОДА, відділами культури і туризму ОТГ, відділами культури і туризму райдержадміністрації (далі - РДА), управлінням і відділами культури і туризму виконавчих комітетів рад міст обласного значення. Реформа децентралізації в Україні зумовила зміну адміністративно-територіально устрою в країні, а за ним і трансформацію різних галузей на рівні адміністративнотериторіальних одиниць. Так, протягом років здійснюється зміна системи управління галуззю культури, що була налагоджена ще у 20-30-х роках минулого століття [4].

Управління культури і туризму Рівненської ОДА є структурним підрозділом обласної державної адміністрації, утворюється головою обласної державної адміністрації, входить до складу обласної 148 
державної адміністрації і в межах Рівненської області забезпечує виконання покладених на нього завдань [7]. Відповідно до Положення [7], основними завданнями управління $€$ забезпечення реалізації державної політики в галузі культури і мистецтва, початкової мистецької освіти, туризму і курортів, охорони культурної спадщини, а також державної мовної політики, міжнаціональних відносин, релігії та захисту прав національних меншин України [7].

Крім того, управління здійснює забезпечення вільного розвитку культурно-мистецьких процесів та доступності всіх видів культурних послуг і культурної діяльності для кожного громадянина України. Серед основних напрямків діяльності управління, варто відзначити також сприяння загальнонаціональній культурній консолідації суспільства, формуванню цілісного культурно-інформаційного простору, захисту та просуванню високоякісного різноманітного національного культурного продукту [7].

Реалізацією державної політики у сфері культури на рівні області здійснюють комунальні заклади Рівненської обласної ради, серед яких культурно-археологічний центр «Пересопниця», державний історико-культурний заповідник м. Острога, державний історико-культурний заповідник м. Дубно, Рівненський обласний краєзнавчий музей, Рівненська обласна бібліотека для дітей, Рівненська обласна бібліотека для молоді, Рівненська обласна універсальна наукова бібліотека, Рівненський обласний центр народної творчості, Рівненська обласна філармонія, Рівненський академічний обласний театр ляльок, Рівненський обласний академічний український музично-драматичний театр [7].

Проте на сьогодні управління культури та туризму Рівненської облдержадміністрації опікується не лише комунальними закладами обласного значення, а й іншими закладами культури, що здебільшого зосереджені у районах, містах, селах і селищах Рівненської області. Окрім вищезазначених закладів, до компетенції управління також належать й інші сфери. Наприклад, народне аматорство, організація дозвілля, збереження відродження матеріальної, нематеріальної спадщини, початкова мистецька освіта, музейна справа, національні відносини, релігія, міжконфесійні відносини, сприяння роботі творчих спілок, книговидання, туризм та інші царини дотичні до культури [4].

Основними завданнями відділів культури відповідної РДА $€$ забезпечення на території району реалізації державної політики в галузі культури, туризму, охорони культурної спадщини, дотримання законодавства щодо прав національних меншин, свободи світогляду 
Серія «Економічні науки»

Випуск 3(95) 2021 р.

і віросповідання [8].

Для реалізації державної політики з різних питань у складі територіальних громад створюють органи управління. Проте, в межах економії, функціонують структурні підрозділи, до напрямків діяльності яких може бути віднесено питання культури, туризму, а також молоді, спорту, освіти, соціального захисту та ін. [4]. У такому випадку, розвиток сфери культури у регіоні гальмується недостатньою компетентністю спеціалістів та різноаспектним колом обов'язків фахівців територіальних громад. Таким чином, вимогою сьогодення $\epsilon$ виокремлення окремого сектору з питань реалізації державної культурної політики у складі територіальних громад.

Органи управління у сфері культури сприяють збереженню всіх наявних центрів культури, що перебувають на балансі територіальних громад, проте в процесі реформування виникає низка проблем пов'язаних із функціонуванням цих закладів.

По-перше, районні державні адміністрації зобов'язані передати заклади культури територіальній громаді, а територіальні громади, у свою чергу, не можуть відмовитись прийняти установи у свою власність. Якщо територіальна громада вирішує ліквідувати чи реорганізувати, вона має обов'язково звернутися до Міністерства культури та інформаційної політики щодо погодження реорганізації чи ліквідації. Як зазначає очільник центрального органу виконавчої влади Олександр Ткаченко, «лише після отримання погодження, громада може ухвалювати рішення щодо закриття чи реорганізації закладу» [9].

Окрім того, прослідковується тенденція, що органи влади, та чинне законодавство, не встигаючи за швидкими темпами трансформації галузі, стримують іï розвиток [4]. Проте, остаточний висновок зможемо зробити лише за результатами адміністративної реформи.

В умовах децентралізації, основне завдання управління культури і туризму Рівненської ОДА полягає у моніторингу та контролі за дотриманням законодавства, забезпеченням територіальними громадами прав кожної людини на отримання доступних культурних послуг, методичному супроводі. Територіальні громади, у свою чергу, зобов'язані налагодити культурне дозвілля своїх мешканців [6].

До самоврядних повноважень виконавчих органів місцевих рад належить створення умов для розвитку культури, сприяння відродженню осередків традиційної народної творчості, національно-культурних традицій населення [4]. Заклади культури в 
регіонах, що працюють неефективно, необхідно трансформувати для надання якісних послуг, а не закривати [9]. Проте, викликом для забезпечення ефективного розвивання сфери культури в умовах децентралізації $€$ фінансове забезпечення функціонування галузі, адже заклади культури не отримують субвенції на розвиток [4]. Так, органи публічного управління сферою не втрачають можливості внесення інноваційних змін до їх функціонування та залучення коштів із зовнішніх ресурсів.

Варто відзначити, що ще до реформування адміністративнотериторіального устрою, закладами культури області було розпочато реалізацію пілотних проєктів щодо створення культурно-дозвіллєвих комплексів, що охоплюють заклади соціальної сфери на територіях сільських і селищних рад. Культурно-дозвіллєві комплекси дуже активно працювали і продовжують функціонувати у районах. Так, територіальні громади не втрачають можливості запроваджувати інноваційні форми роботи, і вже роблять спроби створення культурних хабів, що являтиму собою сукупність закладів соціальної сфери. Серед низки адміністративно-територіальних одиниць Рівненщини варто відзначити Тараканівську та Привільненську територіальні громади, які напрацювали чимало проєктів, забезпечили ефективну роботу закладів культури [4], позитивний досвід яких може слугувати зразком для новоутворених територіальних громад.

За ініціювання управління культури та туризму Рівненської ОДА було створено публічно-шкільні бібліотеки, шляхом об'єднання публічних і шкільних бібліотек адміністративно-територіальних одиниць. Проєкт було запроваджено з досвіду реформування у Республіці Польща [4].

Заклади культури у Рівненській області також активно працюють з міжнародними та українськими фондами, донорськими організаціями. За підтримки Української культурного фонду в регіоні вже реалізовано низку проєктів. Варто зазначити, що одним із напрямків розвитку територіальних громад $\epsilon$ налагодження співпраці із різними громадськими організаціями, в тому числі молодіжними.

Відповідно, до інформації, що оприлюднена на офіційному вебсайті Рівненської ОДА [10], вперше управління культури і туризму Рівненської ОДА стало єдиним українським партнером міжнародного проєкту в межах програми «ЄС горизонт 2020», щодо соціальних новацій та технологій для сталого зростання через розвиток культурного туризму, який створить синергію між туристичними 
об'єктами [10].

Крім того, адміністративно-територіальні одиниці області брали участь у конкурсі культурно-мистецьких проєктів «Малі міста великі враження» [11] та отримали фінансову допомогу на реалізацію проєктів, серед яких фестиваль «Енергія мистецтва», всеукраїнський культурно-історичний фестиваль «Добре поруч», Інтерактивний музей стародруків «Державного історико-культурного заповіднику міста Острог» [11]. Безумовно, участь у подібних проєктах не гарантує отримання фінансування, натомість представники територіальних громад отримують досвід, що стане корисним у подальшій грантовій діяльності.

У рамках програми транскордонної співпраці Польщі, України та Білорусі реалізовується проєкт «Культурна спадщина Рівненщини» із бюджетом 59 тис. євро. Впродовж останніх років активувалося залучення коштів через громадський бюджет міста Рівне, зокрема в 2021 році на секторальну підтримку ЄС претендують 22 проєкти на загальну суму 286 млн грн [10].

Стосовно культурної спадщини, то на території Рівненщини зосереджено чимало архітектурних об'єктів, серед яких Тараканівський форт, Квеванський, Дубенський, Новомалинський, Корецький замки, костел Святого Антонія, Благовіщенський костел та ін. Проте згадані пам'ятки, здебільшого, потребують впорядкування та реконструкції.

Оскільки культура регіону охоплює велику кількість об'єктів, вважаємо, що модернізації потребують також бібліотечні, клубні заклади та школи естетичного виховання, які необхідно наповнити новим змістом, на вимогу сьогоднішнього суспільства [4].

Перетворення культурної спадщини у туристичні центри може бути здійснено як державними, так і приватними установами, на балансі яких перебуває об'єкт. Проте, оскільки така трансформація потребує вкладення значних матеріальних ресурсів, багаторазові спроби «нових власників» не дають очікуваних результатів. Управлінням культури і туризму Рівненської ОДА безперервно здійснюються пошуки підприємств, організацій, які посприяли б відновленню національної спадщини [4]. Тому нині основним завданням як управління, так i територіальних громад $\epsilon$ забезпечення цілісності об'єктів у первинному стані. Швидка руйнація архітектурних об'єктів на території регіону, вкотре підтверджує той факт, що ні органи влади, ні місцеве самоврядування не у змозі зберегти та відновити культурну спадщину через брак коштів. 
Відповідно, для відновлення матеріально культурної спадщини доцільно залучення коштів донорських організацій. Так, у результаті лише туристичних проєктів Рівненщини Український культурний фонд профінансував на 4,5 млн грн [10]. Варто також додати, що Міністерством культури і національної спадщини Польщі вже розпочата робота щодо відновлення пам'яток архітектури Волині. Зі слів краєзнавців, по закінченню реставраційних робіт колегіального костелу Святої Трійці (с. Олика), планується відновлення Костелу Благовіщення (с. Клевань). Фахівці у галузі культури, вказують на доцільність передачі пам'яток культурної спадщини на баланс держави, що сприяло б швидкому відновленню пам'яток, а також залученню туристів й науковців до країни [4].

Відновлення архітектурних пам'яток $€$ також пріоритетним напрямом програми Президента України «Велике будівництво. Велика реставрація», на яку від Рівненщини претендують 10 об'єктів. Нині на державному рівні проводиться відбір таких локацій, на відбудову яких передбачать фінансування [10].

Висновки. Дослідження ефективності публічного управління у сфері культури в умовах децентралізації дало можливість виявити причини та наслідки неефективного управління на всіх рівнях, що залежить від організаційних, економічних, правових та соціальних факторів.

Зокрема, заклади культури, у процесі створення нових адміністративно-територіальних одиниць, можуть бути змінені, реорганізовані або ж ліквідовані згідно з потребами місцевої громади. 3 метою економії, у складі територіальних громад функціонують сектори, спектр завдань яких охоплює сфери культури, туризму, освіти, молоді і спорту, а в деяких випадках й інші галузі, що може гальмувати процеси розвитку культури у регіоні. Викликом для територіальних громад постає фінансове забезпечення діяльності закладів культури для забезпечення послуг на належному рівні та підтримання стану об'єктів матеріальної та нематеріальної культурної спадщини. Крім того, прослідковується тенденція, що органи влади, та чинне законодавство, не встигаючи за швидкими темпами трансформації галузі, стримують ії розвиток. Проте, остаточний висновок зможемо зробити за результатами ефективності реформи децентралізації.

Натомість, ефективність публічного управління у сфері культури може бути забезпечена шляхом запровадження інноваційних форм робити на основі вітчизняного та закордонного позитивного досвіду, налагодження співпраці із міжнародними та українськими фондами, 
Серія «Економічні науки»

Випуск 3(95) 2021 p.

трансформації закладів культури відповідно до потреб громади. Крім того, ефективним методом забезпечення сфери матеріальними ресурсами є грантова діяльність.

1. Митник А. А., Бутко Л. В., Данийленко В. Є. Основні проблеми здійснення діяльності закладами культури в умовах децентралізації. Молодий вчений : журнал. 2020. № 10 (86) С. 83-85. 2. Олексенко Р. І. Управління сферою культури в умовах соціально-економічної трансформації. Виклики XXI століття: наука, філософія, освіта : матеріали міжнар. наук.-практ. конф. м. Суми, 21-22 груд. 2019 р. м. Суми. 3. Ситник П. К., Купрійчук В. М., Карлова В. В., Небожук Р. А. Принципи децентралізації державного управління у сфері культури. Інвестиції: практика та досвід. 2020. № 2. С. 89-94. 4. Децентралізаційні виклики управлінням культурою, справами молоді та спорту (Рівненський регіон) : матеріали круглого столу. м. Рівне, 22 квітня 2021 p. URL: https://cutt.ly/0E9TpFU (дата звернення: 09.09.2021). 5. Про культуру : Закон України від 14 грудня 2010 р. № 2778-VI. URL: https://zakon.rada.gov.ua/go/2778-17 (дата звернення: 09.09.2021). 6. Деякі питання діяльності Міністерства культури та інформаційної політики : Постанова Кабінету Міністрів України; Положення від 16 жовтня 2019 р. № 885. URL: https://zakon.rada.gov.ua/go/885-2019-\%D0\%BF (дата звернення: 09.09.2021). 7. Управління культури і туризму : вебсайт. URL: http://cultrv.gov.ua/ (дата звернення: 09.09.2021). 8. Про відділ культури, молоді та спорту Сарненської районної державної адміністрації : Положення від 12 лютого 2020 р. № 25. URL: https://sarny-rda.gov.ua/ (дата звернення: 09.09.2021). 9. Ліквідувати заклад культури можна лише з дозволу MKIП. Укрінформ : вебсайт. URL: https://www.ukrinform.ua/rubric-society/3177740-likviduvati-zaklad-kulturi-moznalise-z-dozvolu-mkip-tkacenko.html (дата звернення: 09.09.2021). 10. 2020-й важкий, але результативний рік у сфері культури Рівненщини. Рівненська обласна державна адміністрація : вебсайт. URL: https://www.rv.gov.ua/news/2020-j-vazhkijale-rezultativnij-rik-u-sferi-kulturi-rivnenshchini (дата звернення: 09.09.2021). 11. Малі міста-великі враження: три проекти Рівненщини стали переможцями. Рівне 1 : вебсайт. URL: https://rivne1.tv/news/105980-mali-mistaveliki-vrazhennya-triproekti-rivnenshchini-stali-peremozhtsyami (дата звернення: 09.09.2021).

\section{REFERENCES:}

1. Mytnyk A. A., Butko L. V., Danyilenko V. Ye. Osnovni problemy zdiisnennia diialnosti zakladamy kultury $v$ umovakh detsentralizatsii. Molodyi vchenyi : zhurnal. 2020. № 10 (86) S. 83-85. 2. Oleksenko R. I. Upravlinnia sferoiu kultury v umovakh sotsialnoekonomichnoi transformatsii. Vyklyky KhKhl stolittia: nauka, filosofiia, osvita : materialy mizhnar. nauk.-prakt. konf. m. Sumy, 21-22 hrud. 2019 r. m. Sumy. 3. Sytnyk P. K., Kupriichuk V. M., Karlova V. V., Nebozhuk R. A. Pryntsypy detsentralizatsii derzhavnoho upravlinnia u sferi kultury. Investytsii: praktyka ta dosvid. 2020. № 2. S. 89-94. 4. Detsentralizatsiini vyklyky upravlinniam kulturoiu, spravamy molodi ta sportu (Rivnenskyi rehion) : materialy kruhloho stolu. m. Rivne, 22 kvitnia 2021 r. URL: https://cutt.ly/0E9TpFU (data zvernennia: 09.09.2021). 5. Pro kulturu : Zakon Ukrainy vid 14 hrudnia 2010 r. № 2778-VI. URL: https://zakon.rada.gov.ua/go/2778-17 (data zvernennia: 09.09.2021). 6. Deiaki pytannia diialnosti Ministerstva kultury ta informatsiinoi polityky : Postanova Kabinetu Ministriv Ukrainy; Polozhennia vid 16 zhovtnia 2019 r. № 885. URL: https://zakon.rada.gov.ua/go/885-2019-\%D0\%BF 
(data zvernennia: 09.09.2021). 7. Upravlinnia kultury i turyzmu : vebsait. URL: http://cultrv.gov.ua/ (data zvernennia: 09.09.2021). 8. Pro viddil kultury, molodi ta sportu Sarnenskoi raionnoi derzhavnoi administratsii : Polozhennia vid 12 liutoho $2020 \mathrm{r}$. № 25. URL: https://sarny-rda.gov.ua/ (data zvernennia: 09.09.2021). 9. Likviduvaty zaklad kultury mozhna lyshe $z$ dozvolu MKIP. Ukrinform : vebsait. URL: https://www.ukrinform.ua/rubric-society/3177740-likviduvati-zaklad-kulturi-moznalise-z-dozvolu-mkip-tkacenko.html (data zvernennia: 09.09.2021). 10. 2020-y vazhkyi, ale rezultatyvnyi rik u sferi kultury Rivnenshchyny. Rivnenska oblasna derzhavna administratsiia : vebsait. URL: https://www.rv.gov.ua/news/2020-j-vazhkij-alerezultativnij-rik-u-sferi-kulturi-rivnenshchini (data zvernennia: 09.09.2021). 11. Mali mista-velyki vrazhennia: try proekty Rivnenshchyny staly peremozhtsiamy. Rivne 1 : vebsait. URL: https://rivne1.tv/news/105980-mali-mistaveliki-vrazhennya-tri-proektirivnenshchini-stali-peremozhtsyami (data zvernennia: 09.09.2021).

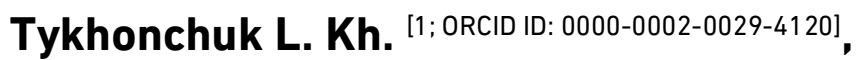
Doctor of Science in Public Administration, Associate Professor, Chubok T. 0. [1; ORCID ID: 0000-0001-6807-8232], Master

${ }^{1}$ National University of Water and Environmental Engineering, Rivne

\section{EFFICIENCY OF THE PUBLIC ADMINISTRATION IN CULTURE IN THE CONDITIONS OF DECENTRALIZATION (ON THE EXAMPLE OF RIVNE REGION)}

This article describes the investigation of public administration efficiency in culture in the conditions of decentralization. A necessary condition for ensuring the full development of culture is the organization and implementation of effective public management principles. These are interrelated goals and ways to achieve it, which indicate possible or necessary ways, mechanisms, means to achieve the goal in the development of culture in conditions of decentralization.

The main components of the public administration system in culture in Ukraine are characterized. The basic elements of the state cultural policy are defined. An analysis of the essence and features of the transformation of public administration in culture in the context of decentralization reform. There are detected reasons of inefficiency in public administration of Rivne region. The urgency of introducing changes in the functioning of cultural institutions to meet the needs of the local community in modern conditions is proved. Emphasis is placed on the need for legislative innovations that prohibit the misuse or re-profiling of local cultural institutions to ensure the effectiveness of public administration. The need to develop and implement a new model of cultural institutions in the context of decentralization reform is indicated. Peculiarities of improving the functioning of social sphere 
institutions to ensure the effectiveness of management at the expense of grant organizations, international and Ukrainian funds from the experience of the Rivne region are considered. The expediency of introduction of measures of organizational, legal, and economic character which in a complex will lead to an increase of the level of efficiency of public management in the field of culture is offered and substantiated.

Keywords: culture; decentralization; efficiency of public administration in culture; UKF; grant.

Тихончук Л. Х. ${ }^{[1 ; ~ O R C I D ~ I D: ~ 0000-0002-0029-4120], ~}$

д.н.гос.упр., доцент,

Чубок Т. А. [1; ORCID ID: 0000-0001-6807-8232], соискатель высшего образования второго (магистерского) уровня

${ }^{1}$ Национальный университет водного хозяйства и природопользования, г. Ровно

\section{ЭФФЕКТИВНОСТЬ ГОСУДАРСТВЕННО-ОБЩЕСТВЕННОГО УПРАВЛЕНИЯ В СФЕРЕ КУЛЬТУРЫ В УСЛОВИЯХ ДЕЦЕНТРАЛИЗАЦИИ (НА ПРИМЕРЕ РОВЕНСКОЙ ОБЛАСТИ)}

В статье описано исследование эффективности государственнообщественного управления в сфере культуры в Ровенской области. Осуществлен анализ сущности и особенностей трансформации государственно-общественного управления в сфере культуры в условия реформы децентрализации. Доказывается актуальность внесения изменений в функционировании учреждений культуры с целью удовлетворения потребностей местного сообщества в современных условиях. Акцентировано внимание на необходимости законодательных инноваций, запрещающие нецелевое использование или перепрофилирования местных культурных учреждений для обеспечения эффективности государственно-общественного управления. Указывается на необходимость разработки и внедрения новой модели работы учреждений культуры в условиях реформы децентрализации. Рассмотрены особенности улучшения функционирования учреждений социальной сферы для обеспечения эффективности управления за счет грантовых организаций, международных и украинских фондов из опыта Ровенской области.

Ключевые слова: культура; децентрализация; эффективность общественного управления в сфере культуры; УКФ; грант.

Отримано: 10 вересня 2021 р. Прорецензовано: 15 вересня 2021 р. Прийнято до друку: 24 вересня 2021 р. 